\title{
Late Tertiary fault activity in the southwestern boundary fault system of the Roer Valley Graben: evidences from the Bree area (NE Belgium)
}

\author{
M. Sintubin ${ }^{1, \star}$, O. Sels ${ }^{2} \&$ P. Buffel ${ }^{3}$
}

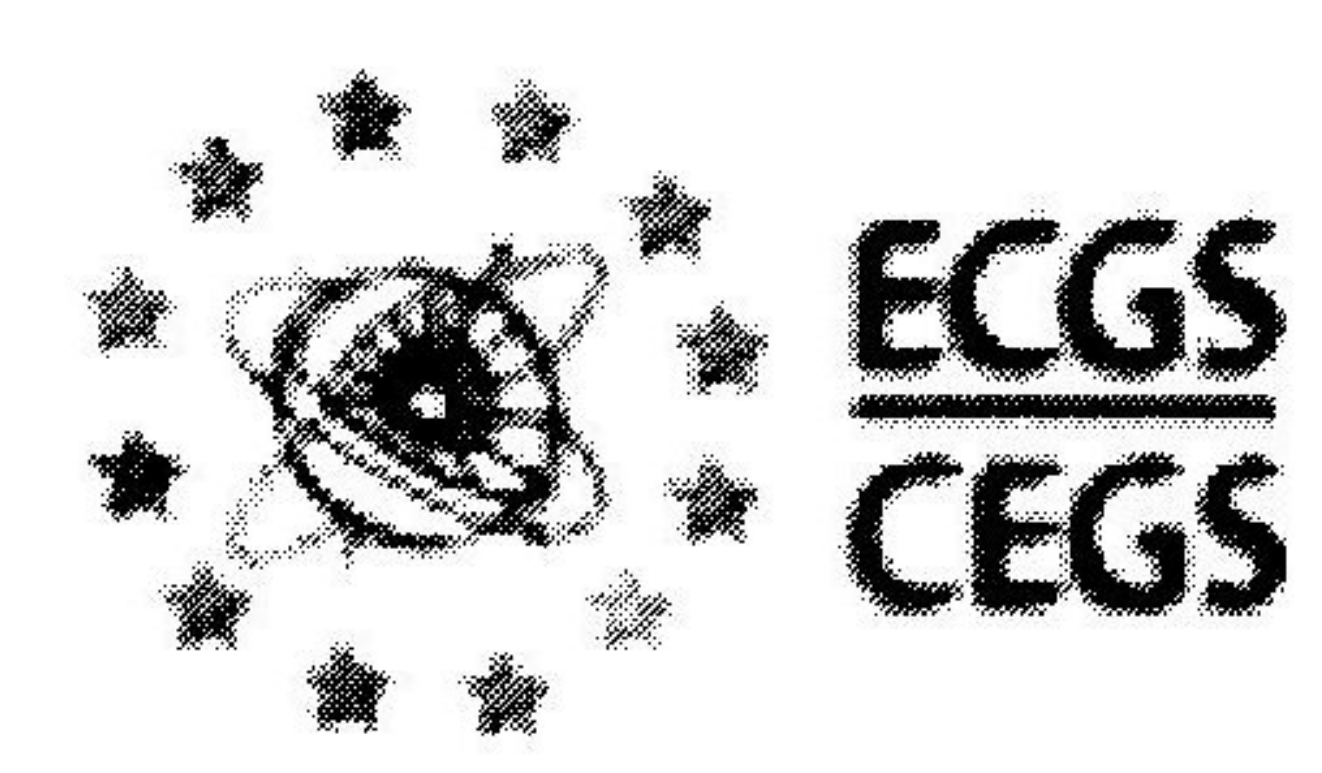

1 Structurele Geologie \& Tektoniek, K.U.Leuven, Redingenstraat 16, B-3000 Leuven; e-mail: manuel.sintubin@geo.kuleuven.ac.be

2 GEDAS, Clara Snellingsstraat 27, B-2100 Deurne

3 Geological Service Company, Houwaartstraat 31, B-3210 Linden

* corresponding author

Manuscript received: July 2000; accepted: April 2001

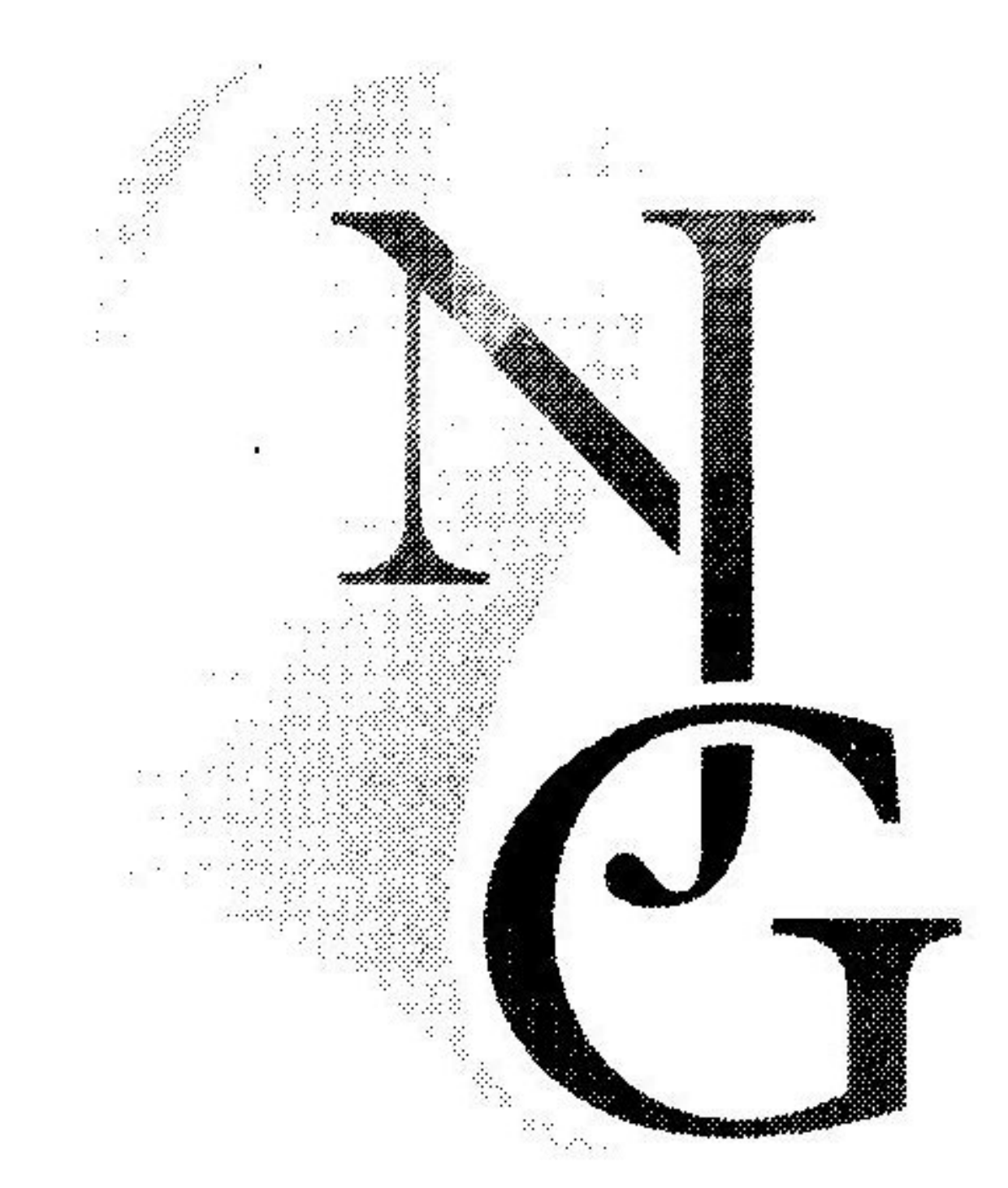

\begin{abstract}
The Bree Uplift is a particular structure in the direct footwall of the southwestern graben boundary fault system of the Roer Valley Graben, which has been firstly recognized at the base of the Cretaceous. To date fault activity around the Bree Uplift has been confined to the Subhercynian (late Cretaceous) inversion event or considered fading out during Tertiary times.

The revision of the existing geological data reveals that the Bree Uplift can still be recognized on the top-Tertiary map. This infers at least a late Tertiary activity, suggesting continuous fault activity in the graben boundary fault system not only on the major boundary faults but also on different splay faults, bounding individual fault blocks.
\end{abstract}

Keywords: Bree Uplift, Campine Basin, Miocene, Pliocene, Roer Valley Graben

\section{Introduction}

In the Bree area (NE Belgium) the southwestern boundary fault system of the Roer Valley Graben shows some particular features at the base of the Cretaceous (Fig. 1): (1) the convergence of the Heerlerheide and Feldbiss faults; (2) the bifurcation towards the north into the Grote Brogel, Reppel and BocholtHamont faults; and (3) the presence of two fault blocks, the Bree Uplift and the Op-den-Berg fault block. The latter structures are currently interpreted (Langenaeker, 1999; 2001) as the result of a Subhercynian (late Cretaceous) dextral transpressional deformation episode acting on the graben boundary fault system. Demyttenaere (1989) and Langenaeker $(1999 ; 2001)$ do not consider more recent fault activity around the Bree Uplift, while Rossa (1986) considered a gradually fading activity into the Tertiary. Late Tertiary activity, however, has to date never been considered.
During the revision of the geological maps of Belgium, sheet 18-10 Maaseik-Beverbeek (Sels et al., 1999) and sheet 26 Rekem (Buffel et al., 1999), a number of stratigraphical and sedimentological incompatibilities arose in the Neogene deposits in the direct footwall of the graben boundary fault system in the Bree area.

Already Mourlon (1898) observed a relatively thin series of Diest Sands overlying white Bolderberg Sands, contrary to what was generally observed in the region (see Gullentops \& Huyghebaert, 1999). A reinterpretation of the borehole data in the Bree area seems to confirm Mourlon's observation. Because at that time there was no knowledge of faults in this area, because of the absence of deep boreholes or seismic profiles, Mourlon (1898) assumed that the Diest Sands were deposited concordantly on top of the Bolderberg Sands (Mourlon, 1898).

In the current paper it will be demonstrated, based on a reinterpretation of existing data as well as on 
new observations that the Bree Uplift can still be recognized on the top-Tertiary map. This implies at least late Tertiary activity on the faults limiting the Bree Uplift. The outline of this particular structure will be constrained, taking into account of the geometry of the Bree Uplift at the base of the Cretaceous (Langenaeker, 1999; 2001).

\section{Geologic setting}

The area of interest is situated along the southwestern boundary fault system of the Roer Valley Graben (Fig. 1). The graben boundary fault system is expressed in both the Mesozoic and Cenozoic stratigraphical distribution, indicating a repeated activity since Palaeozoic times (Demyttenaere, 1989; Langenaeker, 1999; 2001). On the subcrop map at the base of the Cretaceous (Langenaeker, 1999; 2001) the Jurassic is only subcropping in the hanging wall of the graben boundary fault system. On the top-Tertiary map (Fig. 2) the Pliocene Kiezeloöliet Formation is again only developed in the hanging wall of the graben boundary fault system (Figs. $2 \& 4$ ). The Mol Formation, on the other hand, which is assumed to be a time-equivalent facies of the Kiezeloöliet Formation (Sels et al., 1999), only occurs in the footwall of the graben boundary fault system (Fig. 2).

Geomorphologically the graben boundary fault system is, moreover, expressed by a number of prominent linear scarps (Paulissen, 1997; Paulissen et al., 1985). Recently, trenching has revealed important mainly Pleistocene activity on the graben boundary fault system (Camelbeeck \& Meghraoui, 1998).

South of Bree, the graben boundary fault system (Fig. 1) consists of two major faults, the Heerlerheide-Rotem and Feldbiss-Neeroeteren faults. While the former shows major Cimmerian activity, the latter predominantly shows Tertiary to recent activity (Demyttenaere, 1989; Rossa, 1986). Towards the north both faults converge. Commonly the Heerlerheide fault is considered a splay fault of the Feldbiss fault (Langenaeker, 2001). North of Bree, three major faults are considered to be kinematically equivalent to the Heerlerheide-Feldbiss fault system (Fig. 1). Although Langenaeker (2001) considers the Grote Brogel fault as the graben boundary fault, most of the displacement in both Cimmerian and late Tertiary episodes is observed along the Bocholt-Hamont fault. The Reppel fault, finally, is situated inbetween the Grote Brogel and Bocholt-Hamont faults. The prolongation of the Heerlerheide-Feldbiss fault system into the Reppel-Bocholt-Hamont fault system, as

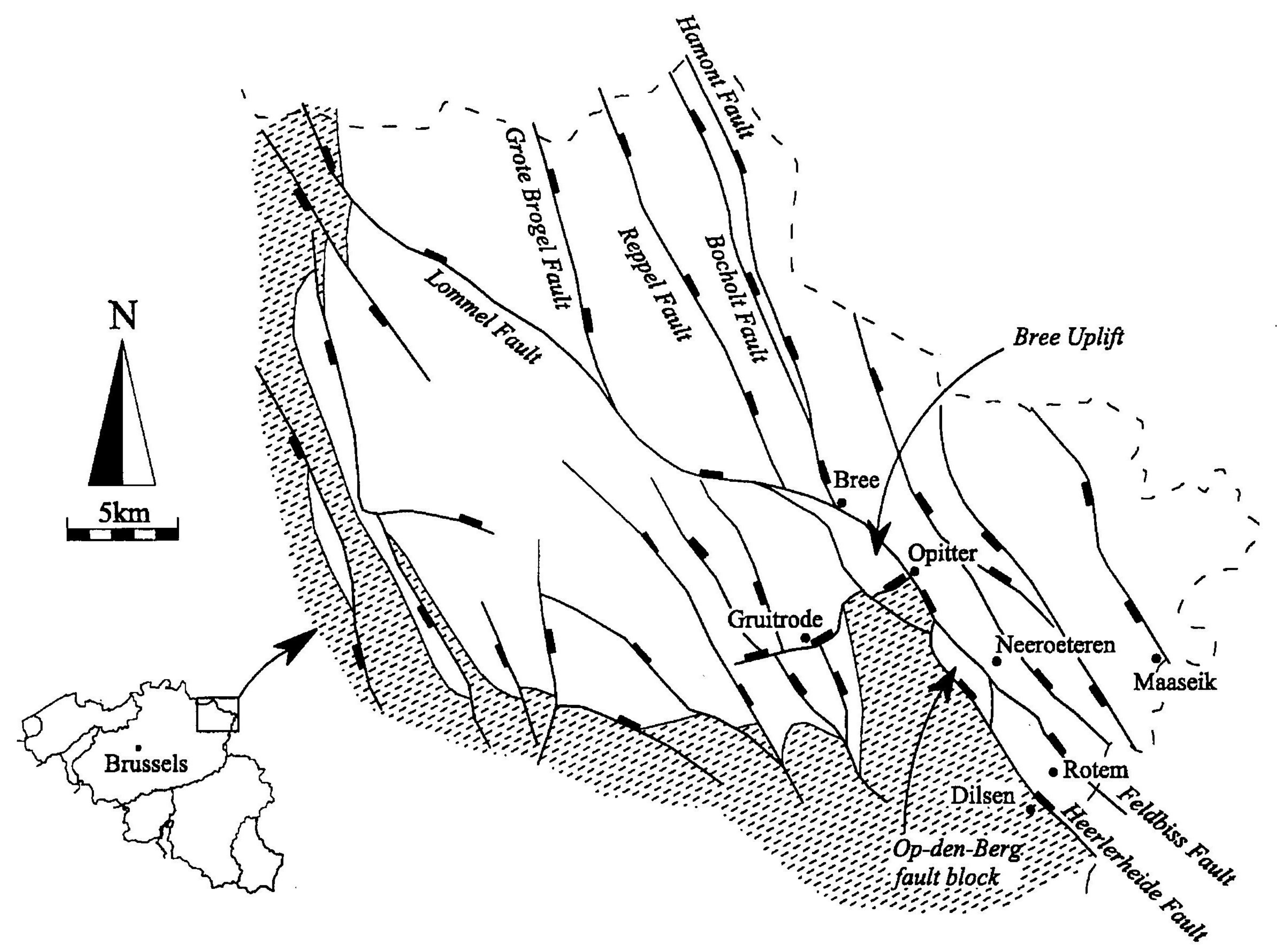

Fig. 1. Subcrop map at the base of the Cretaceous with the main faults of the southwestern boundary fault system of the Roer Valley Graben (NE Belgium). Hatched area is where Palaeozoic rocks are subcropping (after Langenaeker, 2001). 


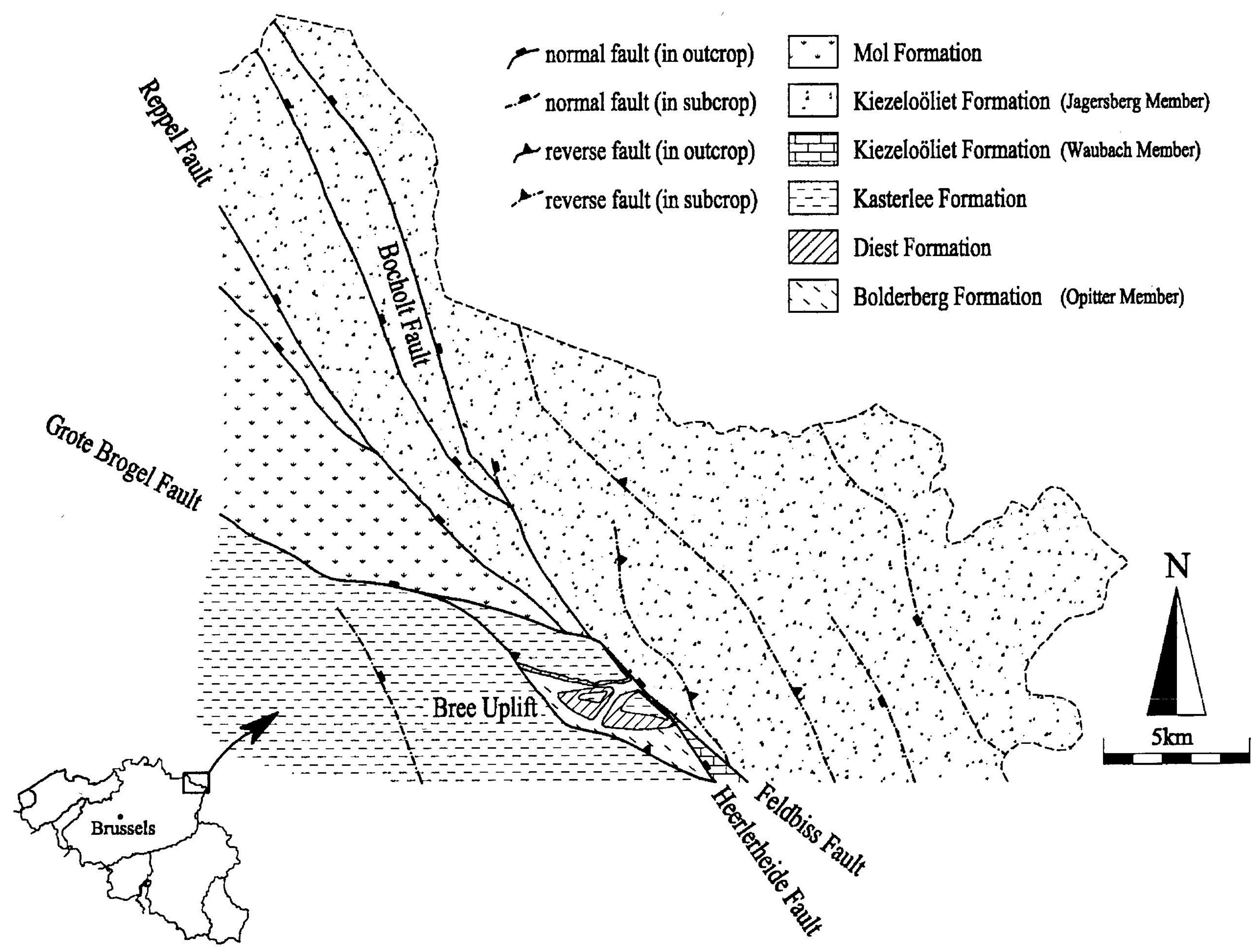

Fig. 2. Revised top-Tertiary map (sheet 18-10 Maaseik-Beverbeek - after Sels et al., 1999).

suggested by the above-mentioned particular stratigraphical distributions, is moreover corroborated by a linear high on the gravity anomaly map (Everaerts, pers. Comm.).

In the direct footwall of the graben boundary fault a broad high can be recognized between Dilsen and Bree (Fig. 1), formerly called the Neeroeteren-Rotem Horst (Grosjean, 1939). In this area Palaeozoic rocks are directly subcropping underneath the Cretaceous cover (Fig. 1), similar to the situation on the Peel Horst (Rossa, 1986). A number of particular structural features characterize this high. Contrary to the overall structuration of the Palaeozoic series in the Campine Basin, the Palaeozoic series in the high are characterized by open, NW-SE-trending, folds (Bouckaert et al., 1981), which are roughly parallel to the fault traces. Striking, however, is that towards the graben boundary fault (Heerlerheide fault) the fold trend curves into a more NNE-SSW orientation.

Directly south of Bree a positive Bouguer anomaly has been observed (Bouckaert et al., 1981). The geological feature, associated with this anomaly, seems to have a major influence on the geometry of the graben boundary fault system. On the one hand, the faults seem to circumscribe the anomaly. On the other hand, while along the anomaly the graben boundary fault system consists of only one major fault, both to the north and south of the anomaly the fault system consists of a number of bifurcated faults.

\section{Bree Uplift - a short review}

On top of this positive Bouguer anomaly a particular structural high in the direct footwall of the graben boundary fault, the Bree Uplift, has been defined on seismic sections (Bouckaert et al., 1981). This elongated $(10 \times 2 \mathrm{~km})$ structure is characterized by a reduced Upper Cretaceous cover sequence, indicating a Subhercynian activity on the fault system (Langenaeker, 2001).

Whereas Bouckaert et al. (1981) still considered the Bree Uplift as an integral part of the NeeroeterenRotem Horst, Rossa (1986) identified an E-dipping fault bordering the Bree Uplift to the southwest (fault $\mathrm{k}$ - Rossa, 1986). He considers this fault as the northern continuation of the Heerlerheide fault. The main rise of the Bree Uplift takes place in the Campanian. Its inverse activity constantly slows down in the Tertiary. Miocene activity is considered local and rather hypothetical (Rossa, 1986). 
Eversince the Bree Uplift is considered as a faultbounded structural unit in the footwall of the Heerlerheide-Feldbiss fault system. Fault $\mathrm{k}$ of Rossa (1986) is renamed by Demyttenaere (1989) as the Bree fault. According to Demyttenaere (1989), recently concurred by Langenaeker $(1999 ; 2001)$, the activity on the southwestern border fault of the Bree Horse ceased after the Subhercynian inversion. Contrary to Rossa (1986), no trace of any Tertiary activity has been described by both authors.

Kinematically this particular structure is currently interpreted as a half positive flower structure, caused by an uplift in a restraining bend of the graben boundary fault system generated during a dextral transpressional deformation episode (Dusar \& Langenaeker, 1992; Langenaeker, 1999; 2001). Similarly the Op-den-Berg fault block, just south of the Bree Uplift (Fig. 1), has been interpreted as a half negative flower structure, situated in a releasing bend of the graben boundary fault system (Langenaeker, 1999; 2001).

\section{Stratigraphical evidences}

By means of a re-evaluation of the historical observations, the proper observations and a re-interpretation of the relevant borehole data in the Bree area, evidence is given of some stratigraphical particularities in the direct footwall of the graben boundary fault zone. The stratigraphical interpretation is backed up by new grain-size analyses (see Gullentops \& Huyghebaert, 1999).
Data

\section{Opitter quarry}

In the abandoned Opitter quarry, situated at a few hundred meters west of fault scarp (Fig. 3), representing the surface trace of the graben boundary fault (Heerlerheide-Feldbiss fault), the following section can be observed:

- a 1 to $2.6 \mathrm{~m}$ thick unit of light-green sands, with at its base a pebble horizon with fragments of ferruginous sandstone (de Heinzelin, 1963); grain-size analysis show that these sands are rather well-sorted sands with a mean grain size of around $170 \mathrm{~mm}$; the glauconite content is relatively low (10 to $15 \%$ of total amount of grains);

- a 4 to $5 \mathrm{~m}$ thick unit of darker-green clayey, strongly bioturbated (annelid tubulations), coarse-grained sands with a high glauconite content (up to $50 \%$ ); grain-size analysis show that these sands are badly sorted and have a mean grain size of around $250 \mathrm{~mm}$; at the base some small quartz pebbles and strongly decalcified shells are found; this horizon is interpreted as a beach layer;

- a unit of at least $7 \mathrm{~m}$ of white, micaceous sands; in a $4 \mathrm{~m}$ deep drill hole these white sands are still encountered, clearly indicating that the white color is not due to decoloration or a change in facies; these sands are well-sorted with a mean grain size of around $140 \mathrm{~mm}$; these sands contain almost no glauconite; glauconite-rich tubulations may be present, however.

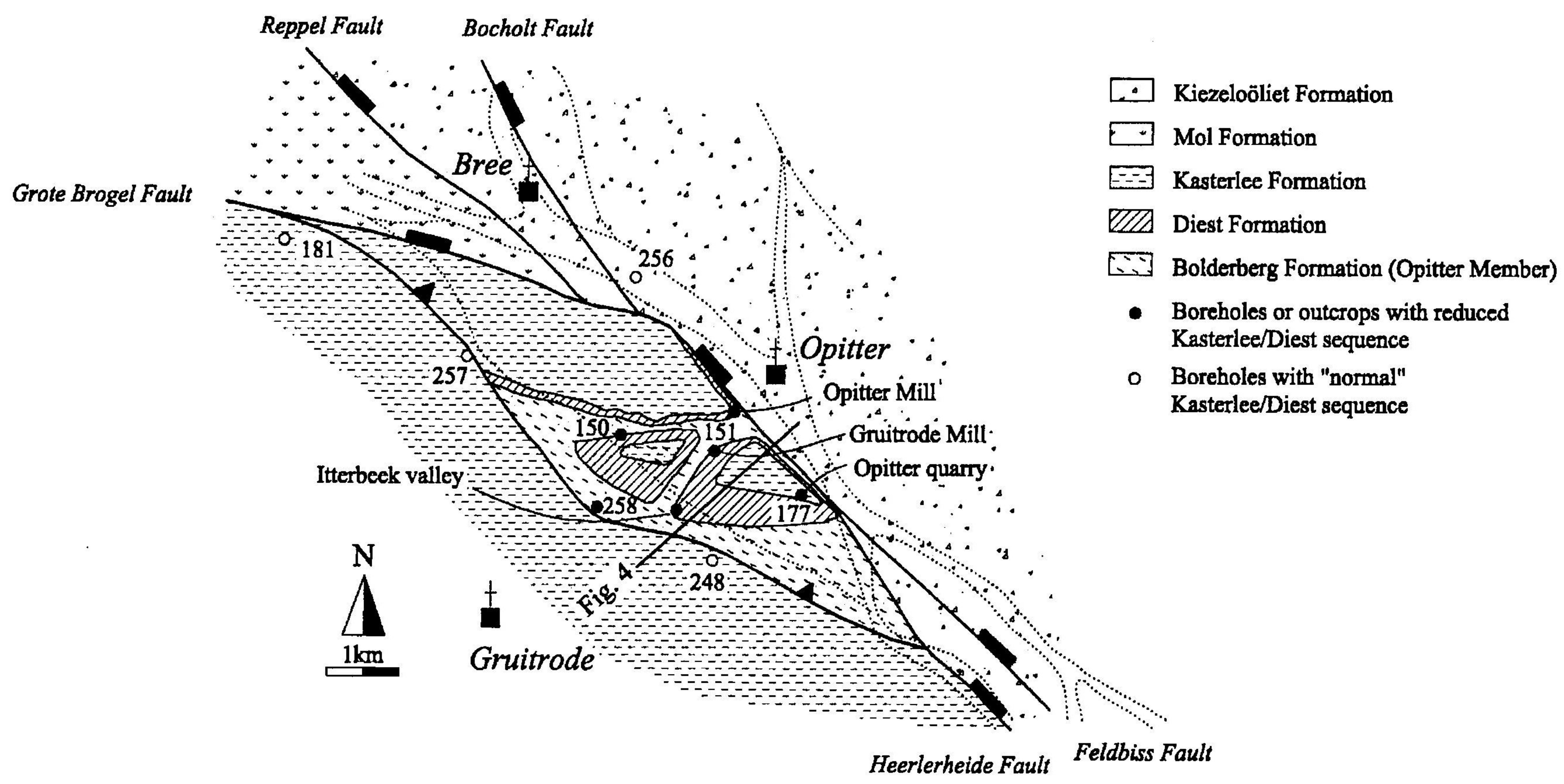

Fig. 3. Top-Tertiary map of the Bree area. Dotted lines represent the fault-zone traces at the base of the Cretaceous (after Langenaeker, 2001). Indication of all relevant data points. 


\section{Itterbeek valley}

In the Itterbeek valley the same dark-green sands as in the Opitter quarry are observed in outcrop. Grain-size analysis confirms this correlation. White sands are, however, within reach by hand drillings. A grain-size analysis shows that these sands have the same signature as the white sands at the base of the Opitter quarry.

\section{Opitter Mill (Pollismolen)}

The same succession of at least $3 \mathrm{~m}$ of dark-green, bioturbated, sands, overlying at least $6 \mathrm{~m}$ of pure white sands, has been observed in an outcrop behind the Opitter Mill (Fig. 3). Again, a grain-size analysis confirms the correlation. Also, the beach layer has been recognized at the base of the upper sand unit.

\section{Gruitrode Mill (Rooiermolen)}

Mourlon (1898) described the same succession on this now vanished outcrop (Fig. 3). By means of hand drillings, Mourlon (1898), moreover, shows that the white sands have a total thickness of $9 \mathrm{~m}$ with a gravelly base. de Heinzelin (1963) describes a cross-lamination in the lower part of this white sand unit.

\section{Belgian Geological Survey boreholes}

Based on the borehole data (see appendix for a more detailed description) in the wider area it becomes obvious that the sequences observed in the outcrops in the Bree area show some particularities, clearly deviating from the regional sequence in the footwall of the graben boundary fault system. It should be noticed that in the lithological descriptions of the boreholes the limit between the two glauconite-bearing sands is often difficult to determine.

In boreholes 48E248, 48E257 and 48W181 (Fig. 3 ) the 'normal' sequence is observed, consisting of more than $50 \mathrm{~m}$ of dark green, glauconite-rich coarse sands before the white sands (up to $100 \mathrm{~m}$ thick in borehole 48E248) are reached.

In the Bree area a number of boreholes (48E258, 48E150, 48E151 and 48E177 - Fig. 3) again show a deviation of this regional pattern. Only a thin layer, with a maximum thickness of $6 \mathrm{~m}$, of the dark-green, glauconite-rich sands is observed, overlying the white sands. The thickness of the latter sands could never been determined because the boreholes were never deep enough.

\section{Interpretation}

In the footwall of the graben boundary fault system three formations are currently of interest. In the
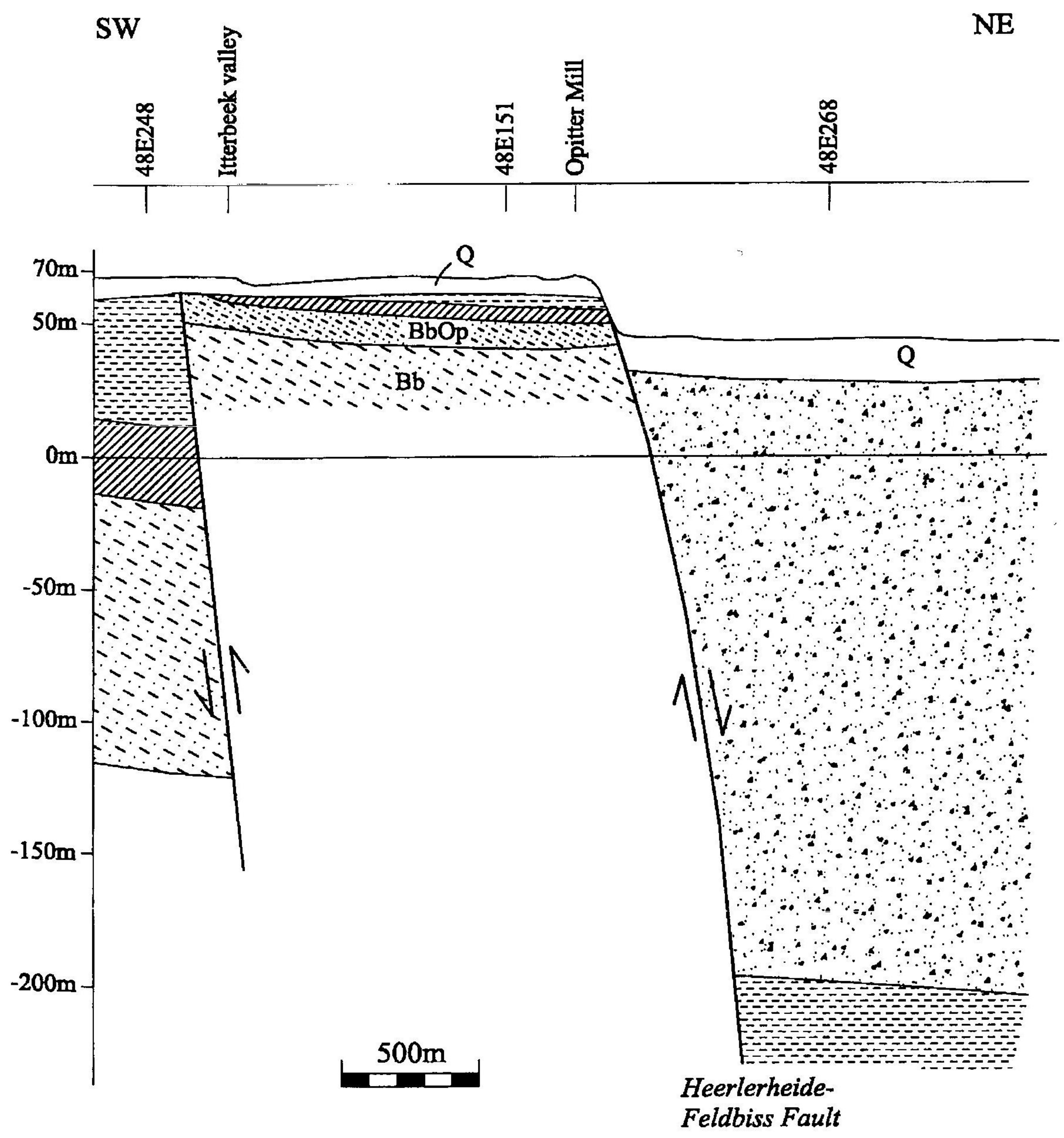

Fig. 4. Itterbeek valley cross section. See Fig. 3 for legend. $\mathrm{Q}=$ Quaternary; $\mathrm{BbOp}=$ Bolderberg Formation, Opitter Member; Bb $=$ Bolderberg Formation, undifferentiated (after Sels et al., 1999). 
hanging wall these formations are buried underneath a thick sequence (more than $200 \mathrm{~m}$ ) of gravel and coarse sands, called the Kiezeloöliet Formation (Upper Pliocene) (Figs. $3 \& 4$ ).

The upper glauconite-bearing sands belong to the Kasterlee Formation (early Pliocene). Its normal thickness exceeds $30 \mathrm{~m}$. The underlying, glauconiterich, coarse-grained sands can be identified as the Diest Formation (late Miocene). The normal thickness in the area varies between 50 and $100 \mathrm{~m}$ because of the erosive character of the Diest Formation. These sands are deposited in deep erosion channels cutting into the underlying formations. Finally, the underlying white, medium to coarse-grained pure sands with a small amount of glauconite, forms the upper part of the Bolderberg Formation (late Miocene).

In the proximity of the graben boundary fault system, just southwest of Bree, however, a number of stratigraphical inconsistencies are observed in both outcrops and boreholes. The different formations show a particular facies and a reduced thickness. A detailed sedimentological description of these formations in the Bree area can be found in Gullentops \& Huyghebaert (1999).

The Kasterlee Formation has a thickness of only a few meters. The sands are well sorted. Gullentops \& Huyghebaert (1999) interpret these sands as deposited on a wave platform. At the base a gravel horizon may be present, indicative of an erosive contact with the underlying Diest Sands (cf. Gullentops \& Huyghebaert, 1999). Also the Diest Formation has a thickness of only 2 to $4 \mathrm{~m}$. The base consists of a pebble horizon with decalcified shells, interpreted as a beach layer (Gullentops \& Huyghebaert, 1999). These sands, moreover, show a finer grain size and a lower glauconite content than normal. Again these sands are interpreted to have been deposited on a coastal platform at the outskirts of an erosion channel, eroding the underlying sands. Finally, the upper part of the Bolderberg Formation shows a particular facies. Fine-grained, well-sorted sands underlain by a gravel horizon (Mourlon, 1898) define a separate stratigraphical unit, called the Opitter Member (Sels et al., 1999). This unit has a minimum thickness of $9 \mathrm{~m}$. Its presence in the upper part of the Bolderberg Formation outside the Bree area remains to date a matter of discussion. Also, these sands are considered to have been deposited on a wave platform.

\section{Geometrical inferences}

The rather limited area, in which these stratigraphical inconsistencies occur, occupies a very particular position in the direct footwall of graben boundary fault system. It largely coincides with the extent of the socalled Bree Uplift as defined at the base of the Cretaceous (Langenaeker, 1999; 2001). These stratigraphical differences infer that the outline of the Bree Uplift can still be recognized on the top-Tertiary map (Sels et al., 1999). All outcrops in the area, as well as boreholes 48E258, 48E150, 48E151 and 48E177 are situated within the limits of this structure (Fig. 3). An outline of the Bree Uplift on the top-Tertiary map is proposed purely based on an extrapolation of the outline at the base of the Cretaceous.

Due to a weak tilting of the strata, resulting in a northeastern overall dip, and the incision of both the Itterbeek and the Eetsevelderbeek, all three formations are cropping out on the top-Tertiary map, thus defining the Bree Uplift. The northeastern limit of this structure is well defined by the morphological fault scarp, which resulted from quaternary activity on the graben boundary fault. An apparent normal throw of more than $250 \mathrm{~m}$ is obvious. The southwestern limit of the structure has, however, to date not been defined properly. A faulted contact is assumed primarily based on the abrupt change in the westernmost part of the Itterbeek valley (Fig. 4). While in the last outcrop in the Itterbeek valley the white sands of the Bolderberg Formation are directly subcropping, the top of the Bolderberg Formation is only reached in borehole $48 \mathrm{E} 248$ underneath an approximately $80 \mathrm{~m}$ thick sequence of Kasterlee and Diest Sands. An apparent reverse displacement of approximately $80 \mathrm{~m}$ can thus be inferred. The attitude of this border fault can not be constrained properly. On seismic section the bad resolution only allows the identification of a disturbed zone. Exact location, extend and attitude of the assumed fault can not be determined. A northeastern dip, parallel to the graben boundary fault, is assumed, again primarily based on an extrapolation of the border fault at the base of the Cretaceous. Similar to the Bree Uplift at the base of the Cretaceous a half-graben fault block in the footwall of the graben boundary fault is thus apparent on the top-Tertiary map. This southwestern border fault may thus link up with the fault $k$ of Rossa (1986) or the Bree fault of Demyttenaere (1989).

\section{Kinematic inferences}

Taking into account the sedimentological characteristics of the three formations within the outline of the top-Tertiary Bree Uplift (Gullentops \& Huyghebaert, 1999) an interaction between fault activity along this structure and sedimentation of these sands may be inferred. Based on the presence of the particular Opitter Member at the top of the Bolderberg Formation, 
consisting of marine sands deposited on a wave platform, the existence of a high during late-Miocene times can be postulated. Activity on the reverse southwestern border fault thus occurred before the end of the Miocene. Also the erosive nature of the Diest Formation, its reduced thickness and its particular facies, characteristic for deposition on a coastal platform at the outskirts of the main channel (Gullentops \& Huyghebaert, 1999) indicates the presence of a high as well as fault activity during the early Pliocene. The question can moreover be asked if a active fault scarp defined the border of the main channel in this area. A post-Diestian fault activity is apparent based on the displacement at both sides of the southwestern border fault. Also the Kasterlee Sands are deposited on a wave platform, strongly eroding the underlying sands. This again indicates the presence of a high during the deposition of the Kasterlee Sands and most probably a reverse fault activity during sedimentation.

A nearly continuous reverse fault activity during late Miocene and early Pliocene times can thus be assumed on the southwestern border fault, probably associated with a continuous normal fault activity on the graben boundary fault, gradually squeezing out a pop-up structure, the Bree Uplift, in the graben shoulder.

No indications are found for Quaternary activity on the southwestern border fault, contrary to the graben boundary fault, which activity continuous up to very recent times (cf. Camelbeeck \& Meghraoui, 1998).

\section{Discussion}

The stratigraphical and sedimentological particularities in the direct footwall of the graben boundary fault southwest of Bree clearly indicate a reverse fault activity along the southwestern border fault of the Bree Uplift during late Tertiary times. Due to the erosive contact between the different formations, the displacement associated with this late Tertiary fault activity can, however, not be constrained properly.

These conclusions are thus in contradiction with the observations of Langenaeker $(1999 ; 2001)$ and Demyttenaere (1989), who limit the presence of this structure at the base of the Cretaceous and do not recognize any post-Subhercynian activity on the southwestern border fault of the Bree Uplift. The observations, on the other hand, complement the observations of Rossa (1986), who still recognizes the Bree Uplift at the base of the Miocene, although the displacement seems negligible. Rossa (1986) considers a decreasing activity on the fault during Tertiary time, fading out before the Miocene. The seemingly contra- diction of the current conclusions with the observations of Rossa (1986) may be due to the resolution of the technique applied. Rossa's conclusions are based on the interpretation of seismic sections, of which the resolution is rather poor in the upper part. Our conclusions, on the other hand, are based on direct field observations, allowing a much higher resolution. In this respect our conclusions have not to be considered as contradictory to those of Rossa (1986) but as a refinement, extending the fault activity along the southwestern border fault into the Pliocene.

The assumption made to define the outline of the Bree Uplift on the top-Tertiary map, based on the continuity of the limiting faults, remains very hypothetical. Although no indications can be found in boreholes nor on seismic sections, it can not be excluded that the southwestern border fault, as defined at the base of the Cretaceous (Demyttenaere, 1989; Langenaeker, 1999; 2001), can not be extrapolated to the surface, and that different superimposed structures have to be considered, bordered by distinct faults, splaying off from the graben boundary fault at different levels. Indeed, the three-dimensional architecture, as well as the linking of the different faults in the area, remains a matter of discussion.

Finally, the true kinematics remains hypothetical. The Bree Uplift at the base of the Cretaceous is interpreted as a pop-up structure on the graben shoulder, squeezed out during dextral transpressional deformation conditions during the Subhercynian inversion in a restraining bend of graben boundary fault system. The question can indeed be asked if the presence of the Bree Uplift on the top-Tertiary map implies that these particular deformation conditions prevailed throughout the Tertiary.

\section{Conclusions}

To date it was inferred from seismic data that fault activity around the Bree Uplift ceased after the Subhercynian inversion event (Demyttenaere, 1989; Langenaeker, 1999; 2001) or gradually faded in the Tertiary (Rossa, 1986). Based on detailed stratigraphy in outcrops and boreholes, it has been demonstrated in the current paper that the Bree Uplift is still present on the top-Tertiary map (Sels et al., 1999), extending the observations of Rossa (1986) into the Pliocene. Based on sedimentological characteristics it could moreover be inferred that the Bree Uplift acted as a high during Miocene and Pliocene sedimentation in the area, implying continuous reverse fault activity on its southwestern border fault.

The recognition of a continuous fault activity around the Bree Uplift from Cretaceous time on- 
wards clearly complies with the recent conviction of a continuous Tertiary and Quaternary activity in the graben boundary fault system, as recently revealed by trenching (Camelbeeck \& Meghraoui, 1998).

\section{Acknowledgements}

This work was part of the Tertiary mapping project of the Natural Resources Division (A..N.R.E.) of the Ministry of the Flemish Community (Belgium). It also frames in the project GEO/97-3.10 of the Belgian Geological Survey (Department of Economic Affairs, Belgium). Discussions with $\mathrm{N}$. Vandenberghe, $M$. Dusar, F. Gullentops greatly improved the current work.

\section{References}

Bouckaert, J., Dusar, M. \& Van de Velde, E., 1981. Exploration for coal in the Neeroeteren-Rotem area (Campine coalfield of the Campine-Brabant Basin NE Belgium). Preliminary results of a seismic survey carried out in December 1980 - January 1981. Annales de la Société géologique de Belgique, 104: 281-289.

Buffel, P., Claes, S. \& Gullentops, F., 1999. Geologische kaart van België, kaartblad Rekem (26) \& verklarende tekst. Ministerie van de Vlaamse Gemeenschap, Brussel.

Camelbeeck, T. \& Meghraoui, M., 1998. Geological and geophysical evidence for large palaeo-earthquakes with surface faulting in the Roer Graben (northwest Europe). Geophys. J. Int., 132: 347-362.

de Heinzelin, J., 1963. Compte Rendu des excursions: descriptions des affleurements, Symposium sur la stratigraphie du Néogène nordique. Mémoires de la Société belge de Géologie, Gent, pp. 222-246.
Demyttenaere, R., 1989. The post-Paleozoic geological history of north-eastern Belgium. Mededelingen van de Koninklijke Academie voor Wetenschappen, Letteren en Schone Kunsten van België, Klasse der Wetenschappen, 51: 51-81.

Dusar, M. \& Langenaeker, V., 1992. De oostrand van het Massief van Brabant, met beschrijving van de geologische verkenningsboring te Martenslinde. Professional Papers of the Belgian Geological Survey, 255: 1-22.

Grosjean, A., 1939. Sur la limite septentrionale du gisement houiller accesible en Campine. Les premiers résultats $\mathrm{du}$ sondage de Rotem (Schootslei). Bulletin de la Société Belge de Géologie, 49: 210-217.

Gullentops, F. \& Huyghebaert, L., 1999. Neogene stratigraphy in the Itter Valley, Roer Valley Graben rim, Belgium. Aardkundige Mededelingen, 9: 143-146.

Langenaeker, V., 1999. Indications for a transpressional late Cretaceous inversion in the belgian part of the Roer Valley Graben. Aardkundige Mededelingen, 9: 139-142.

Langenaeker, V., 2001. The Campine Basin. Stratigraphy, structural geology, coalification and hydrocarbon potential for the Devonian to Jurassic. Aardkundige Mededelingen, 10: 1-142.

Mourlon, M., 1898. Sur les dépôts tertiaires de la Campine limbourgeoise à l'ouest de la Meuse. Bulletin de la Société belge de Géologie, 12: 45-58.

Paulissen, E., 1997. Quaternary morphotectonics in the Belgian part of the Roer Graben. Aardkundige Mededelingen, 8: 131134.

Paulissen, E., Vandenberghe, J. \& Gullentops, F., 1985. The Feldbiss fault in the Maas valley bottom (Limburg, Belgium). Geologie en Mijnbouw, 64: 79-87.

Rossa, H.G., 1986. Upper Cretaceous and Tertiary inversion tectonics in the western part of the Rhenish-Westphalian coal district (FRG) and in the Campine area (N Belgium). Annales de la Société géologique de Belgique, 109: 367-410.

Sels, O., Claes, S. \& Gullentops, F., 1999. Geologische kaart van België, kaartblad Maaseik-Beverbeek (18-10) \& verklarende tekst. Ministerie van de Vlaamse Gemeenschap, Brussel. 


\section{Appendix - Description and interpretation of the BDG boreholes}

\section{E150}

\begin{tabular}{lll}
\hline depth & Lithology & Interpretation \\
\hline Om-1m50 & $\begin{array}{l}\text { gravel mixed with gravely yellowish sand transferring in } \\
\text { glauconite bearing quartz sand with pebbles in contact with the } \\
\text { underlying clay }\end{array}$ & $\begin{array}{l}\text { Quaternary with reworked Kasterlee and } \\
\text { Diest formations }\end{array}$ \\
\hline $1 m 50-1 m 80$ & clay with yellow and white glimmers & \\
\hline $1 m 80-3 m 20$ & $\begin{array}{l}\text { whitish en yellowish sand with gray clay layers and an occasional } \\
\text { glauconite grain }\end{array}$ & Bolderberg Formation, Opitter Member \\
\hline $3 m 20-7 m 20$ & yellow sand &
\end{tabular}

48E151 (Moulin de Gruitrode)

\begin{tabular}{lll}
\hline depth & Lithology & Interpretation \\
\hline Om-3m30 & $\begin{array}{l}\text { gray quartz bearing glauconite sands with white spots of } \\
\text { annelid tubulations }\end{array}$ & Quaternary and Diest Formation \\
\hline $3 m 30-3 m 60$ & $\begin{array}{l}\text { dark brown gravel layer with fossils, white phosphor concretions } \\
\text { and little pebbles } \\
\text { (Ostrea edulis, Cardium decorticatum, Cyprina Islandica, Cerithium } \\
\text { tricinctum, etc...) }\end{array}$ & $\begin{array}{l}\text { Bolderberg Formation, Opitter Member; } \\
\text { Bolderberg and Voort Formations. Opitter } \\
\end{array}$ \\
& & $\begin{array}{l}\text { The boundary between Bolderberg and Voort } \\
\text { Formations possibly between 32m20 and } 41 \mathrm{~m} 50 .\end{array}$ \\
\hline
\end{tabular}

\begin{tabular}{ll}
$3 m 60-9 m 60$ & white glimmer sand with yellow parts \\
\hline $9 m 60-26 m 80$ & $\begin{array}{l}\text { yellow medium fine sand, glimmers and occasional glauconite } \\
\text { grains, sometimes a little darker }\end{array}$
\end{tabular}

$26 m 80-74 m 10$ green rather coarse sand with glimmers; at the base darker, more glimmers and glauconite

$48 \mathrm{E} 177$

\begin{tabular}{llc}
\hline depth & Lithology & Interpretation \\
\hline Om-1m & green glauconite rich sand with gravel and some fossils & Quaternary and Diest Formation \\
\hline $1 m-2 m$ & $\begin{array}{l}\text { yellow fine sand with little glauconite and many glimmers } \\
\text { (resembles } \mathrm{Bb})\end{array}$ & Bolderberg Formation, Opitter Member
\end{tabular}

\section{$48 W 181$}

\begin{tabular}{lll}
\hline Depth & Lithology & Interpretation \\
\hline $0 m-8 m$ & whitish sand with gravel & Quaternary \\
\hline $8 m-16 m$ & whitish half-fine sand with some coarser elements & $\begin{array}{l}\text { Kasterlee and Diest Formations. Boundary } \\
\text { between Kasterlee and Diest Formations possibly } \\
\text { between } 24 \mathrm{~m} \text { and } 32 \mathrm{~m} .\end{array}$ \\
\hline
\end{tabular}

\begin{tabular}{ll}
\hline $16 m-20 m$ & white grayish rather fine sand \\
\hline $20 m-24 m$ & idem but very heteromorphous and hard clay fragments \\
\hline $24 m-32 m$ & heteromorphous gray greenish sand with a piece of wood \\
\hline $32 m-52 m$ & heteromorphous gray greenish sand with clayey parts
\end{tabular}




\begin{tabular}{|c|c|c|}
\hline Depth & Lithtology & Interpretation \\
\hline $0 m-15 m$ & fine yellow loamy sand with pebbles, mixed with white sand & Quaternary \\
\hline $15 m-32 m$ & fine yellow loamy sand with clay parts & $\begin{array}{l}\text { Kasterlee and Diest Formations. Boundary } \\
\text { between Kasterlee and Diest Formations possibly } \\
\text { between } 32 \mathrm{~m} \text { and } 37 \mathrm{~m} \text {. }\end{array}$ \\
\hline $32 m-72 m$ & dark green glauconite rich micaceous medium to course sand & \\
\hline $72 m-82 m$ & fine dark green glauconite rich micaceous bearing sand & \\
\hline $82 m-107 m$ & idem mixed with brown sand with wood fragments & Bolderberg Formation \\
\hline $107 m-152 m$ & $\begin{array}{l}\text { dark brown medium to coarse micaceous quartz sand with silex } \\
\text { and peat-like wood }\end{array}$ & \\
\hline $152 m-187 m$ & idem but fine and with fragments of shells & \\
\hline
\end{tabular}

$187 m-252 m \quad$ very fine green sand with shell fragments of glycymeris and corals Voort Formation

$48 \mathrm{E} 257$

\begin{tabular}{|c|c|c|}
\hline Depth & Lithology & Interpretation \\
\hline $0 m-9 m$ & yellowish brown sand with loam, coarse gravel & Quaternary \\
\hline $9 m-14 m$ & fine white sand & Kasterlee Formation \\
\hline $14 m-30 m$ & bluish black solid clay with fine sand & \\
\hline $30 m-59 m$ & green sand with black dots & Diest Formation \\
\hline \multicolumn{3}{|l|}{$48 \mathrm{E} 258$} \\
\hline depth & Lithology & Interpretation \\
\hline $0 m-5 m 50$ & loam with gravel & Quaternary \\
\hline $5 m 50-15 m$ & loam with sand & \\
\hline $15 m-23 m 50$ & white sands & Bolderberg Formation \\
\hline
\end{tabular}

